\title{
Proteinúria: muito mais que uma simples dosagem
}

A dosagem de albuminúria ou, de forma mais abrangente, de proteinúria é considerada marcador sensível não apenas de lesão renal, mas também de doenças cardiovasculares de um modo geral, o que lhe confere papel de destaque como instrumento diagnóstico.

Em certo sentido, não se pode dizer que a determinação da excreção urinária de proteína seja atualmente um exame mais relevante que quando foi desenvolvido, no século XVIII, o primeiro método para sua realização, porém hoje seu âmbito de utilização é maior e a aplicabilidade para diagnóstico precoce dessas doenças é amplamente reconhecida. Além disso, o conhecimento atual sobre os possíveis interferentes e as variadas causas de erro inerentes ao exame exigem maior cuidado com o processamento da amostra e a análise propriamente dita, face às consequências diagnósticas, prognósticas e terapêuticas, que resultados falsamente positivos ou negativos acarretam.

A determinação da excreção urinária de proteínas totais e, em especial, da fração albumina constitui-se no exame mais sensível e aplicável, no dia a dia, para detecção precoce de doença renal crônica (DRC), condição cuja prevalência vem aumentando de forma muito rápida em nossos dias.

Se tal constatação, por si só, já é preocupante, fica ainda pior quando se observa que o número de doentes sem diagnóstico é muito superior ao atualmente detectado, e que a DRC tem participação relevante no aumento do risco cardiovascular, com amplas repercussões na morbimortalidade geral em todo o mundo. Atualmente, a DRC é vista como um problema de saúde pública, cujo tratamento se caracteriza por custo muito elevado, em especial quando se fala em tratamento de substituição renal. Sua prevenção representa a melhor solução.

Sendo a DRC uma condição cujos desenvolvimento e ocorrência não podem ser completamente evitados por medidas higieno-dietéticas ou tratamentos medicamentosos, a melhor forma de redução dos danos é o diagnóstico precoce. Este, por sua vez, não pode depender de sintomas, visto que, na maior parte dos casos, a sintomatologia é discreta, inexistente ou tardia. Por tudo isso, ganha destaque a pesquisa de proteinúria (ou albuminúria) como instrumento para diagnóstico precoce e consequente prevenção secundária. Uma vez detectada a proteinúria, o acompanhamento dos níveis desse marcador com vistas à sua redução, ou mesmo negativação, passam a ser as grandes metas do tratamento.

Vale salientar que o crescimento na prevalência da DRC não é decorrente de doenças intrinsecamente renais, como se poderia esperar; é de fato determinado por doenças sistêmicas que, secundariamente, lesam os rins, como a doença aterosclerótica e o diabetes mellitus, sendo esta última a causa mais frequente de DRC terminal em países desenvolvidos. Nesse contexto, vem à lembrança o papel da pesquisa de proteinúria, em especial da microalbuminúria, para diagnóstico do acometimento renal no curso do diabetes mellitus e a perspectiva de reversão do processo, quando o tratamento se faz na fase inicial da nefropatia, evitando-se a progressão para síndrome nefrótica e insuficiência renal terminal.

Considerando o exposto até aqui, a importância da pesquisa e/ou dosagem de proteinúria é inquestionável e apresenta como uma de suas vantagens o fato de estar disponível até no mais simples laboratório de Patologia Clínica. Entretanto, é preciso estar ciente que realizar as determinações de proteinúria, albuminúria e microalbuminúria exige mais atenção e cuidados do que em geral se tem dado até o momento. Ainda existem indefinições em relação à melhor forma de realizar os exames, interpretar os resultados e expressar os valores de referência na prática diária. 
A título de exemplo, a importância da proteinúria (albuminúria) é incontestável para o nefrologista, mas pode não ser tão evidente para os demais especialistas, sejam eles clínicos ou cirurgiões, quer cuidem de crianças, adultos ou idosos, quando estão diante de um resultado alterado. De fato, qualquer que seja a indicação que motivou a realização do exame, a detecção de proteinúria (albuminúria) nunca deveria ser deixada de lado sem a devida confirmação e/ou investigação; mas não é raro um paciente com doença renal bem definida ter, entre seus exames de urina antigos, documentação de proteinúria (albuminúria) que não foi devidamente valorizada, sequer relatada para o portador da alteração, perdendo-se, assim, a oportunidade de fazer o diagnóstico precoce.

No que se refere às formas de mensurar a proteinúria, a medida tradicional em 24 horas tem o grande inconveniente que é a coleta de duração prolongada, associada à imprecisão no resultado decorrente dos erros de uma coleta cronometrada mal feita. Procurando evitar os inconvenientes citados, tem-se utilizado, cada vez mais, o índice (relação ou razão) proteína/creatinina, cujos resultados apresentam boa correlação com os da proteinúria de 24 horas, considerada padrão-ouro. Entretanto, se por um lado o índice contorna os problemas de coleta, por outro ele possui algumas deficiências inerentes à dosagem de creatinina, dependentes do paciente (p. ex., sexo e massa muscular) ou da metodologia utilizada (p. ex., interferentes analíticos e calibração), ou devidas à albumina (ou proteínas totais), incluindo o período do dia em que se procede à coleta.

Por sua relevância e possíveis causas de erro em diferentes etapas de sua determinação, os laboratórios devem estar preparados para esclarecer os pacientes sobre as condições do dia a dia que podem interferir nos resultados da dosagem de proteinúria (como exercício recente, febre nos últimos três dias) e atender a solicitações diferenciadas e amplamente embasadas no conhecimento clínico, como determinação da excreção de proteinúria (ou albuminúria) corrigida pela excreção urinária de creatinina e determinação em amostras coletadas em repouso e após exercício (conforme especificado pelo médico assistente ou de acordo com a padronização do próprio laboratório).

Ainda do ponto de vista do clínico, a utilização de unidades pouco comuns para relatar os resultados é uma complicação a mais que se associa à variabilidade observada, por exemplo, quando os exames são realizados em laboratórios diferentes. Esse é um dos aspectos abordados na revisão Current Issues in Measurement and Reporting of Urinary Albumin Excretion, traduzida do Clinical Chemistry para o JBPML (1), e que trata de fatores relevantes nas etapas pré-analíticas, analíticas e pós-analíticas do exame, cujo desconhecimento pode ter repercussões significativas sobre o resultado final. Nessa revisão acentuam-se, entre outros, aspectos a que muitos profissionais podem não atentar, como interferências decorrentes do armazenamento em geladeira ou freezer e cuidados essenciais com a amostra no momento da dosagem.

A partir do que já expusemos e do que é amplamente discutido nesse excelente artigo, hoje é preciso questionar se a determinação da proteinúria deve ser encarada como um exame simples. Certamente, podemos continuar dizendo que ele é simples em sua execução, desde que seja feito com o conhecimento de todas as suas peculiaridades e respeitados todos os cuidados inerentes a cada etapa da realização de um teste laboratorial.

\section{Referência}

1. MILLER, W. G. et al.; on behalf of the National Kidney Disease Education Program - IFCC Working Group on Standardization of Albumin in Urine. Questões atuais relativas à dosagem e à descrição da excreção urinária de albumina. JBPML, v. 46, n. 3, p. 187-206, 2010. 